\title{
Intravitreal chemotherapy in the management of retinoblastoma in a resource-limited setting
}

\begin{tabular}{|c|c|}
\hline $\begin{array}{l}\text { Authors: } \\
\text { Kashmira Raw } \\
\text { Teboho Seobi } \\
\text { Aubrey Makg }\end{array}$ & $\begin{array}{l}\mathrm{jee}^{1,2} \text { (1) } \\
\mathrm{i}^{2} \text { (1) } \\
\mathrm{tloe}^{2,3} \text { (1) }\end{array}$ \\
\hline $\begin{array}{l}\text { Affiliations: } \\
{ }^{1} \text { Department } \\
\text { Ophthalmolos } \\
\text { of Neuroscien } \\
\text { of the Witwat } \\
\text { Johannesburg }\end{array}$ & $\begin{array}{l}\text { ff } \\
\text { y, Faculty } \\
\text { ces, University } \\
\text { ersrand, } \\
\text { South Africa }\end{array}$ \\
\hline $\begin{array}{l}{ }^{2} \text { Department } \\
\text { Ophthalmolog } \\
\text { Neuroscience } \\
\text { Maxeke Johan } \\
\text { Academic Hos } \\
\text { Johannesburg }\end{array}$ & $\begin{array}{l}\text { f } \\
\text { y, Faculty of } \\
\text {, Charlotte } \\
\text { nesburg } \\
\text { pital, } \\
\text { South Africa }\end{array}$ \\
\hline $\begin{array}{l}{ }^{3} \text { Department } \\
\text { Ophthalmolog } \\
\text { Vitreoretinal } \\
\text { Faculty of NeL } \\
\text { University of } \\
\text { Witwatersran } \\
\text { Johannesburg }\end{array}$ & $\begin{array}{l}\text { f } \\
y \text { and } \\
\text { ervice, } \\
\text { rosciences, } \\
\text { he } \\
\text {, South Africa }\end{array}$ \\
\hline $\begin{array}{l}\text { Correspondin } \\
\text { Kashmira Raw } \\
\text { kashmira_raw }\end{array}$ & $\begin{array}{l}\text { g author: } \\
\text { jee, } \\
\text { ee@yahoo.com }\end{array}$ \\
\hline $\begin{array}{l}\text { Project regist } \\
\text { Project numb }\end{array}$ & $\begin{array}{l}\text { ation number: } \\
\text { er: R14/49 }\end{array}$ \\
\hline $\begin{array}{l}\text { Dates: } \\
\text { Received: } 15 \text { J } \\
\text { Accepted: } 11 \\
\text { Published: } 11\end{array}$ & $\begin{array}{l}\text { uly } 2021 \\
\text { Nov. } 2021 \\
\text { an. } 2022\end{array}$ \\
\hline $\begin{array}{l}\text { How to cite tr } \\
\text { Rawjee K, Seo } \\
\text { Makgotloe A. } \\
\text { chemotherap } \\
\text { management } \\
\text { retinoblastom } \\
\text { resource-limit } \\
\text { Afr Vision Eye } \\
2022 ; 81(1) \text {, a } \\
\text { org/10.4102/ }\end{array}$ & $\begin{array}{l}\text { is article: } \\
\text { oi T, } \\
\text { ntravitreal } \\
\text { in the } \\
\text { of } \\
\text { a in a } \\
\text { ed setting. } \\
\text { Health. } \\
\text { 92. https://doi. } \\
\text { veh.v81i1.692 }\end{array}$ \\
\hline $\begin{array}{l}\text { Copyright: } \\
\text { (c) 2022. The } \\
\text { Licensee: AOS } \\
\text { is licensed un } \\
\text { Creative Comr } \\
\text { Attribution Lic }\end{array}$ & $\begin{array}{l}\text { uthor(s). } \\
\text { S. This work } \\
\text { ler the } \\
\text { nons } \\
\text { ense. }\end{array}$ \\
\hline Read online: & \\
\hline 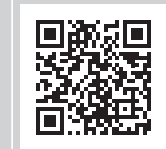 & $\begin{array}{l}\text { Scan this QR } \\
\text { code with your } \\
\text { smart phone or } \\
\text { mobile device } \\
\text { to read online. }\end{array}$ \\
\hline
\end{tabular}

Authors:

Affiliations:

${ }^{1}$ Department of

Ophthalmology, Faculty

of the Witwatersrand,

artment of

Neurosciences, Charlotte

Maxeke Johannesburg

Academic Hospital,

${ }^{3}$ Department of

Ophthalmology and

Vitreoretinal Service,

Faculty of Neurosciences,

University of the

Corresponding author:

Kashmira Rawjee,

Project registration number:

Dates:

Accepted: 11 Nov. 2021

How to cite this article:

Rawjee K, Seobi T,

Makgotloe A. Intravitrea

chemotherapy in the

retinoblastoma in

resource-limited setting.

Copyright:

is licensed under the

Creative Commons

Attribution License.

Scan this QR

to read onlin
Intravitreal chemotherapy (IVitC) in the management of retinoblastoma has increased the rate of globe salvage, specifically in patients with recurrent disease and associated vitreous seeds. A significant number of children with retinoblastoma in developing countries present late, resulting in higher intraocular tumour-stage at presentation. Treatment requirements for such tumours usually include intravenous chemotherapy (IVC) and/or intra-arterial chemotherapy (IAC). While IVC has a long usage track record and a good efficacy, it has been reported to be associated with higher recurrence rates in a significant number of patients. Intra-arterial chemotherapy has the advantage of lower recurrence rates but requires personnel with advanced interventional radiology skills and has limited efficacy in treating intravitreal seeds. Intravitreal chemotherapy has gained popularity recently, largely because of its superior efficacy in the management of vitreous seeds, subretinal seeds and recurrent retinal tumour. An 8-month-old male infant initially presented with bilateral retinoblastoma, International Classification System for Intraocular Retinoblastoma (ICRB) Group E in the right eye and Group B on the left eye. The right eye was enucleated and currently has a prosthesis. The left eye had tumours that initially responded to brachytherapy and transpupillary thermotherapy (TTT). Approximately two years later his tumours recurred with vitreous seeds and were successfully managed with the use of cryotherapy and intravitreal chemotherapy. The simplicity of the technique of IVitC and its efficacy in controlling vitreous seeds and recurrent retinal tumours makes this route of regional chemotherapy a viable one in areas with limited expertise and resources such as South Africa.

Keywords: retinoblastoma; ocular oncology; intravitreal chemotherapy; vitreous seeds; melphalan; topotecan.

\section{Introduction}

Retinoblastoma is the most common intraocular malignancy reported in children. ${ }^{1}$ It accounts for $2 \%-4 \%$ of childhood cancers in the developed world compared with $10 \%-15 \%$ in Africa where it is a significant life-threatening neoplasm. ${ }^{1,23}$ The overall 5-year survival rate in a 20-year review of the disease in Johannesburg, South Africa was reportedly $57.7 \%$. This is a largely discernible contrast to the United States where the survival rates are greater than $95 \% .{ }^{1,2,3}$ A delay in presentation resulting in extraocular extension has been accounted for as the reason for this discrepancy in survival rates. ${ }^{3}$

The management of retinoblastoma is multidisciplinary and based on the group in the case of intraocular retinoblastoma and stage of the presenting tumour as classified by the International Classification System for Intraocular Retinoblastoma (ICRB) (Table 1) ${ }^{1}$ and the International Classification of Retinoblastoma Staging System (Table 2), ${ }^{4}$ respectively. The treatment ranges from local tumour ablation only in Group A, and often involves chemotherapy either systemically or regionally via the intra-arterial and intravitreal routes. ${ }^{1,2,3,5,6}$ In resource-limited settings where patients invariably present later, the initiation of treatment could be further delayed by the need to refer patients to appropriately equipped and staffed centres.

The surgical skill required to administer intravitreal injection makes this therapeutic modality attractive to low-resource settings. We present a retinoblastoma patient whose management included intravitreal chemotherapy (IVitC) for recurrences and vitreous seeds. This case highlights the importance of adding this treatment modality in the retinoblastoma armamentarium in lowresource settings.

\section{Patient presentation}

A 4-year-old male patient first presented to our paediatric ophthalmology service with bilateral retinoblastoma at the age of eight months, with right eye leukocoria. His mother had sought 
TABLE 1: The International Classification System for intraocular retinoblastoma.

\begin{tabular}{|c|c|c|}
\hline Group & Description & Specific features \\
\hline$A$ & $\begin{array}{l}\text { Small discrete tumour away } \\
\text { from critical structures }\end{array}$ & $\begin{array}{l}\text { Tumour }<3 \mathrm{~mm} \text { in basal diameter or } \\
\text { thickness, }>3 \mathrm{~mm} \text { from fovea and } \\
>1.5 \mathrm{~mm} \text { from the disc }\end{array}$ \\
\hline B & $\begin{array}{l}\text { Discrete tumour of any size } \\
\text { and location } \\
\text { No vitreous or subretinal seeds }\end{array}$ & $\begin{array}{l}\text { Tumour }>3 \mathrm{~mm} \text { in basal diameter or } \\
\text { thickness or any of the following: } \\
\bullet<3 \mathrm{~mm} \text { from the foveola } \\
\text { - }<1.5 \mathrm{~mm} \text { from the disc } \\
\text { margin }\end{array}$ \\
\hline C & $\begin{array}{l}\text { Discrete retinal tumours of any } \\
\text { size with focal vitreous or } \\
\text { subretinal seeds }\end{array}$ & $\begin{array}{l}\text { One of the following: } \\
\text { - Vitreous and/or subretinal seeds } \\
<3 \mathrm{~mm} \text { from the tumour } \\
\text { - Less than one quadrant of subretinal } \\
\text { fluid in the fundus }\end{array}$ \\
\hline D & $\begin{array}{l}\text { Non-discrete tumours and/or } \\
\text { diffuse vitreous or subretinal } \\
\text { seeds }\end{array}$ & $\begin{array}{l}\text { One of the following: } \\
\text { - Vitreous and/or subretinal seeds } \\
>3 \mathrm{~mm} \text { from the tumour } \\
\text { - More than one quadrant of } \\
\text { subretinal fluid in the fundus }\end{array}$ \\
\hline$E$ & $\begin{array}{l}\text { Eyes that are functionally/ } \\
\text { anatomically destroyed by } \\
\text { the tumour }\end{array}$ & $\begin{array}{l}\text { Extensive retinoblastoma or one of the } \\
\text { following: } \\
\text { - Neovascular glaucoma (NVG) } \\
\text { - Haemorrhage causing opaque media } \\
\text { in the anterior chamber, vitreous or } \\
\text { subretinal space } \\
\text { - Invasion of the post-laminar optic } \\
\text { nerve, choroid > } 2 \mathrm{~mm} \text {, sclera, orbit, } \\
\text { anterior chamber } \\
\text { - Tumour anterior to the anterior } \\
\text { vitreous face including the ciliary body } \\
\text { or iris } \\
\text { - Diffuse infiltrating tumour } \\
\text { - Pthisis bulbi or orbital cellulitis }\end{array}$ \\
\hline
\end{tabular}

Source: Adapted from Rosa Jr. RH, Bloomer MM, Gombos DS, et al., editors. Ophthalmic pathology and intraocular tumours, 2019-2020 Basic and Clinical Science Course. San Francisco, CA: American Academy of Ophthalmology; 2019, p. 289-302

TABLE 2: The International Classification of retinoblastoma staging system. ${ }^{4}$ International classification of retinoblastoma staging system

Stage 0 Intraocular disease. Eye is not enucleated

Stage I Eye enucleated, completely resected histologically

Stage II Eye enucleated, microscopic residual tumour

Stage III Regional extension

- Overt orbital disease

- Pre-auricular or cervical lymph node extension

Stage IV Metastatic disease

a. Haematogenous metastasis (without central nervous system involvement)

- Single lesion

- Multiple lesion

b. Central nervous system extension (with or without any other site of regional or metastatic disease)

- Pre-chiasmatic lesion

- Central nervous system mass

- Leptomeningeal and cerebrospinal fluid disease

Source: Adapted from Fabian ID, Reddy A, Sagoo SM. Classification and staging of retinoblastoma. Community Eye Health. 2018;101(31):11-13

medical care at several primary/secondary healthcare facilities prior to being referred to our hospital, where he received most of his care. His initial examination under anaesthesia (EUA) revealed a large tumour filling twothirds of the vitreous cavity of the right eye, with a B-scan examination and computed tomography (CT) of brain and orbits, confirming calcifications. The left eye also showed three tumours with no vitreous seeds.

\section{Management and outcome}

His right eye was enucleated following intravenous chemoreduction and a prosthesis fitted shortly after healing. The pathology report showed a Stage I tumour neither with the involvement of the choroid nor the optic nerve and no further treatment was required to his right socket.
The child was then referred to the only facility that offered brachytherapy in South Africa at the time, three months from initial presentation, where he received brachytherapy to the three tumours and transpupillary thermotherapy (TTT) to another tumour, all in his left eye. He underwent regular EUAs and RetCam photos for a period of two years and four months, during which time the tumours remained inactive.

He was later observed to have recurrences with overlying vitreous seeds, when he presented for his routine follow up (Figure 1 - RetCam photographs showing lesions of concern) and was started on cryotherapy to the lesions and multiple three weekly IVitC injections of both Melphalan $(20 \mu \mathrm{g}$ in $0.1 \mathrm{~mL})$ and Topotecan $(20 \mu \mathrm{g}$ in $0.1 \mathrm{~mL})$ over a period of ten months. The tumours and the vitreous seeds regressed with this treatment and remained inactive at two months follow up (Figure 2 - RetCam photographs showing regression of tumours with a calcified appearance). This treatment afforded functional vision in his left only eye at the age of four years.

\section{Discussion}

The management of retinoblastoma requires a multidisciplinary team with a focus on preservation of the child's life, prior to that of the eye and potential for vision. Several factors should be taken into account including the size and location of the tumour, laterality of the disease, the presence or absence of vitreous and subretinal seeds, the age of the patient and the visual prognosis. ${ }^{1,2,5}$ Treatment options in retinoblastoma include chemotherapy, both local and systemic; local treatment modalities such as cryotherapy, laser and brachytherapy. External beam radiation is now only used as a last resort because of its major adverse effects. . $^{1,2}$

Intravenous chemotherapy (IVC) has numerous indications and is used in Group A to Group E tumours. ${ }^{5}$ The agents used are vincristine, etoposide and carboplatin, commonly referred to as ' $\mathrm{VEC}^{\prime}{ }^{5,7,8} \mathrm{~A}$ standard and high dose regimen is available with the latter being used for vitreous seeding in some studies. ${ }^{7}$ These agents have been found to achieve tumour control in 100\% of Group A tumours, 93\% of Group B and $90 \%$ of Group C tumours. ${ }^{7}$ In patients with Group D tumours, IVC is able to control the tumour in only $47 \%$ of patients underscoring the difficulty in controlling vitreous seeding. ${ }^{8}$ In Group E tumours, IVC controls only $25 \%$ of tumours. ${ }^{8}$ In order to minimise adverse effects, more localised routes of delivering chemotherapy to the eye have been developed so that higher concentrations of the drug in the eye can be achieved. ${ }^{5}$

Intra-arterial chemotherapy (IAC) involves the delivery of the chemotherapeutic agent to the globe most commonly via the ophthalmic artery. This form of treatment requires specific expertise and is only available at designated centres in Southern Africa. Intra-arterial chemotherapy was more effective in reducing the size of solid tumours (94\%) and for regression of subretinal seeds (95\%), however, it showed less efficacy in treating vitreous seeds (87\%). ${ }^{9}$ 


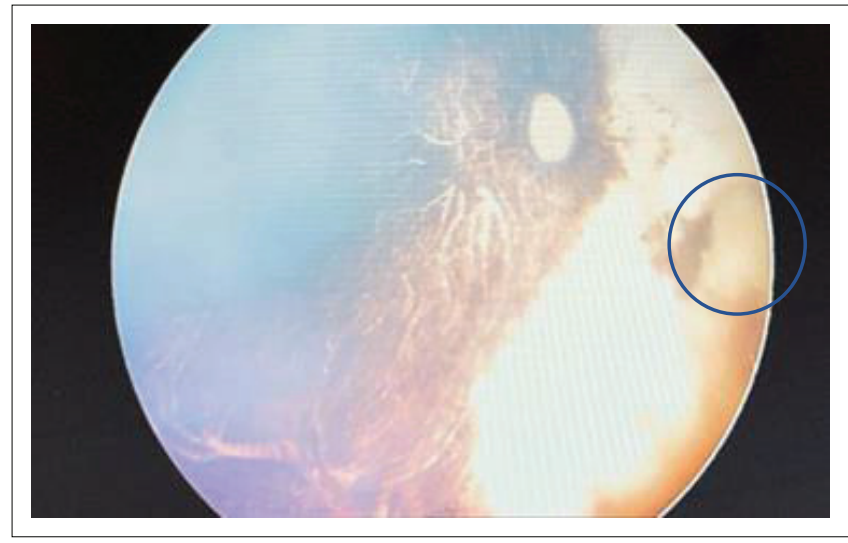

FIGURE 1: RetCam photo of the left eye showing areas of chorioretinal atrophy (Type 4 regression) and an area of concern for reactivation within the circle.

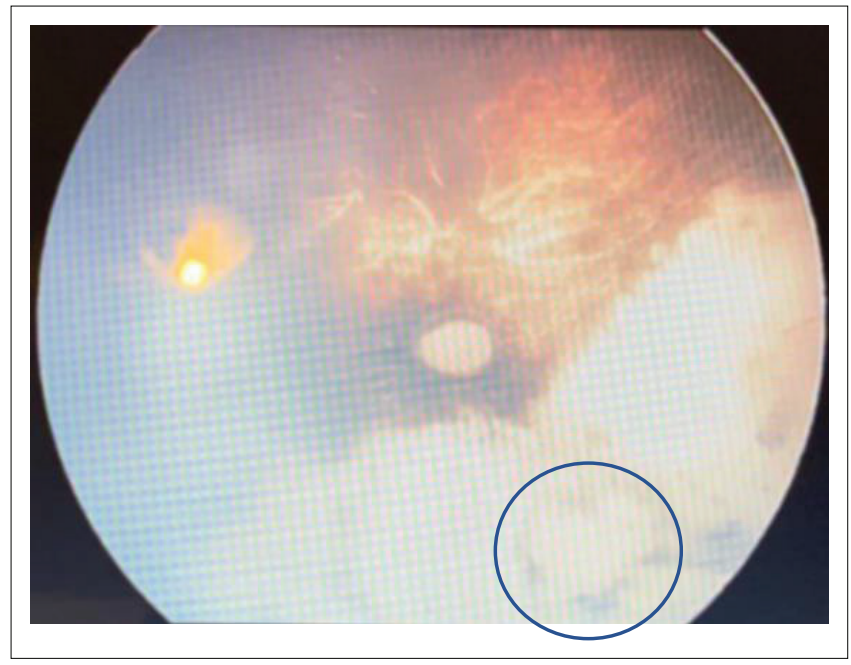

FIGURE 2: RetCam photo showing regressed tumour within the circle.

The challenge in controlling vitreous seeds is attributed to their location in the vitreous, remote from any blood supply. ${ }^{10}$ The use of IVitC is said to increase globe salvage rates in patients with vitreous seeding. ${ }^{10}$ This form of treatment can be used remotely or in conjunction with IVC and IAC. ${ }^{10}$ The technique involves injection of the agent using a sterile technique where no vitreous seeds, subretinal fluid or tumour scars are present within 1-2 h of the injection site. ${ }^{7}$ A paracentesis is performed prior to the injection to prophylactically reduce the intraocular pressure. ${ }^{5} \mathrm{~A} 30$-gauge needle is used at a location $2.5 \mathrm{~mm}-3.0 \mathrm{~mm}$ behind the limbus. The needle is withdrawn through the first ice ball of cryotherapy application. ${ }^{7}$ This has increased the safety profile of the technique by ensuring that any seeds passing through the tract are controlled; this is further enhanced by completing triple freeze-thaw cryotherapy at the site of the injection. ${ }^{7,8}$ The globe is then rotated using a pair of forceps to facilitate distribution of the agent through the vitreous. ${ }^{7,8}$ Complications that may arise during the procedure include vitreous haemorrhage, retinal haemorrhage, endophthalmitis and retinal detachment. At the injection site, conjunctival fibrosis or erythema may occur. ${ }^{10}$ Shields et al. reported none of these complications in their cohort, however cataract and focal pigment epithelial mottling were reported in a small number of patients. ${ }^{10}$
Melphalan is the most extensively used agent and a dose of $20 \mathrm{mg}-30 \mathrm{mg}$ per $0.1 \mathrm{~mL}$ has been reported to be effective for controlling vitreous seeds with minimal toxic side effects. ${ }^{8,10}$ This alkylating agent, exerting its effect during the resting phase of the cell, should be used at a frequency of 7-10 days. Once reconstituted it should be used within 1-2 $\mathrm{h}$ at room temperature. ${ }^{7,8}$ More recently, Topotecan, a topoisomerase I inhibitor has shown significant antitumour activity for retinoblastoma. Its systemic use is limited by the adverse effect of neutropenia, however, its use as an intravitreal injection has several advantages over Melphalan in controlling vitreous seeds. ${ }^{8}$ Injections are given every 3 weeks likely because of the higher vitreous concentration achieved as compared with that of Melphalan. ${ }^{7}$ Once reconstituted with saline, it can be stored for up to four days at room temperature. ${ }^{7}$ These attributes make the drug a worthy alternative in resource limited settings where restricted theatre time and funds are a major factor contributing to the management of patients with retinoblastoma.

These drugs can be used alone or in combination for eyes with recurrent or refractory vitreous seeds during or following treatment with IVC. Shields et al. ${ }^{10}$ achieved vitreous seed control and therefore globe salvage in 100\% of patients with vitreous seeds using an average of 5-weekly injections of $20 \mathrm{mg} / 0.1 \mathrm{~mL}$ of Melphalan. ${ }^{10}$ Topotecan can also be used as a single agent; Rao et al. ${ }^{7}$ achieved vitreous seed control in $100 \%$ of patients using a mean of three intravitreal injections of $30 \mathrm{mg} / 0.15 \mathrm{~mL}$ of Topotecan. ${ }^{7}$ Ghassemi and associates ${ }^{8}$ used a combination of intravitreal Melphalan and Topotecan and achieved control of vitreous seeds in $100 \%$ of patients. ${ }^{8}$

Patients require monitoring every $4-8$ weeks once globe salvaging treatment has been administered to detect activity of seeds, regression or reactivation of tumours. ${ }^{5}$ Once the disease is controlled, the periods between follow up visits can be extended.

\section{Conclusion}

Retinoblastoma may present as a sight and more often in the developing world, as a life-threatening malignancy. When managed promptly and appropriately, survivors of retinoblastoma are able to live through fairly normal childhood experiences. Our patient required several treatment modalities to control the tumour, including IVitC. Given the ease with which this therapy is administered by a general ophthalmologist and its beneficial effects on managing vitreous; subretinal seeding and possibly active retinal tumour lesions, we propose that it should be incorporated early in the treatment of intraocular retinoblastoma in resource-limited settings.

\section{Acknowledgements}

The authors would like to thank the Paediatric Oncology Department at Charlotte Maxeke Johannesburg Academic 
Hospital for their guidance and assistance in the management of this patient.

\section{Competing interests}

The authors declare that they have no financial or personal relationships that may have inappropriately influenced them in writing this article.

\section{Authors' contributions}

K.R., T.S. and A.M. conceived the presented idea. K.R. conducted a literature review and drafted the manuscript. T.S. and A.M. revised the work critically. A.M. approved the final version for publication.

\section{Ethical considerations}

This research report was approved by the Human Research Ethics Council of the University of the Witwatersand. (clearance number M210680).

\section{Funding information}

This research received no specific grant from any funding agency in the public, commercial or not-for-profit sectors.

\section{Data availability}

Data are available upon reasonable request from the corresponding author, K.R.

\section{Disclaimer}

The views and opinions expressed in this article are those of the authors and do not necessarily reflect the official policy or position of any affiliated agency of the authors.

\section{References}

1. Rosa Jr. RH, Bloomer MM, Gombos DS, et al., editors. Ophthalmic pathology and intraocular tumours, 2019-2020 Basic and Clinical Science Course. San Francisco, CA: American Academy of Ophthalmology; 2019, p. 289-302.

2. Hered RW, Archer SM, Braverman RS et al., editors. Paediatric ophthalmology and strabismus, 2019-2020 basic and clinical science course. San Francisco, CA: American Academy of Ophthalmology; 2019, p. 396-404.

3. Goolam S, Kana H, Welsh N, et al. A 20-year retrospective review of retinoblastoma at two Tertiary Academic Hospitals in Johannesburg, South Africa. Ocul Oncol Pathol. 2018;4(3):170-175. https://doi.org/10.1159/000481508

4. Fabian ID, Reddy A, Sagoo SM. Classification and staging of retinoblastoma. Community Eye Health. 2018;101(31):11-13.

5. UpToDate. Retinoblastoma: Treatment and outcome [homepage on the Internet] 2018 [cited 2021 Jan 02]. Available from: https://www.uptodate.com/contents/ retinoblastoma-treatment-and-outcome?search=retinoblastoma\&source=sea ch_result\&selectedTitle $=2 \sim 82 \&$ usage_type $=$ default\&display_rank $=2$

6. EyeWiki. Retinoblastoma [homepage on the Internet]. 2020 [cited 2021 Jan 02]. Available from: https://eyewiki.aao.org/Retinoblastoma\#: : text=Retinoblasto ma $\% 20$ is $\% 20$ an $\% 20$ intraocular $\% 20$ malignancy $\% 20$ with $\% 20$ primitive $\% 20$ neuroendocrine, primarily $\% 20$ affects $\% 20$ young $\% 20$ children. $\% 20$ ICD $10 \% 20$ C69.2\%20ICD9\%20190.5

7. Rao R, Honavar SG, Sharma V, et al. Intravitreal topotecan in the management of refractory and recurrent vitreous seeds in retinoblastoma. $\mathrm{Br} J \mathrm{Ophthalmol}$. 2018;102(4):490-495. https://doi.org/10.1136/bjophthalmol-2017-310641

8. Ghassemi $\mathrm{F}$, Shields $\mathrm{CL}$, Ghadimi $\mathrm{H}$, et al. Combined intravitreal melphalan and topotecan for refractory or recurrent vitreous seeding from retinoblastoma. JAMA Ophthalmol. 2014;132(8):936-941. https://doi.org/10.1001/jamaophthalmol. 2014.414

9. EyeWiki. Intra-arterial chemotherapy for retinoblastoma [homepage on the Internet]. 2019 [cited 2021 Jan 02]. Available from: https://eyewiki.org/Intraarterial_Chemotherapy_for_Retinoblastoma

10. Shields CL, Manjandavida FP, Arepalli S, et al. Intravitreal melphalan for persistent or recurrent retinoblastoma vitreous seeds: Preliminary results. JAMA Ophthalmol. 2014;132(3):319-325. https://doi.org/10.1001/jamaophthalmol.2013.7666 